ENTREPRENEURSHIP AND SUSTAINABILITY ISSUES

ISSN 2345-0282 (online) http://jssidoi.org/jesi/

2021 Volume 8 Number 3 (March)

http://doi.org/10.9770/jesi.2021.8.3(40)
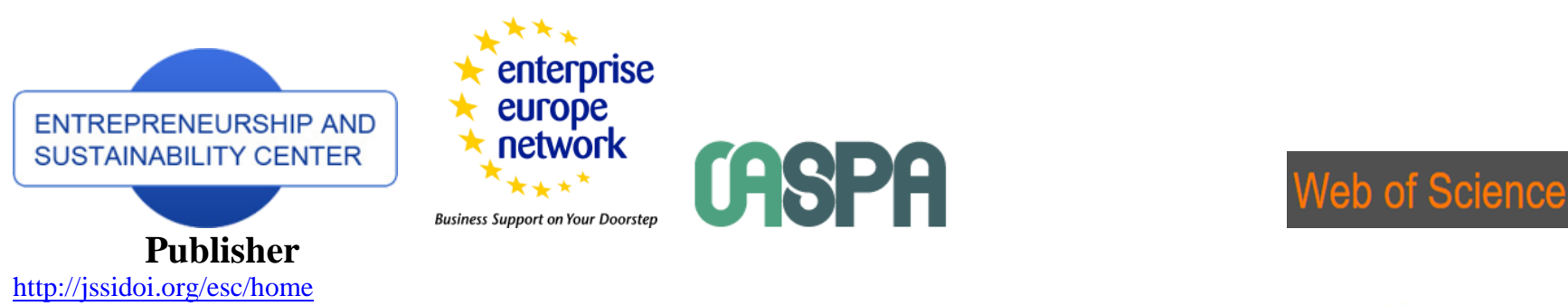

http://jssidoi.org/esc/home

1) Clarivate

Analytics

\title{
TOWARDS MORE SUSTAINABLE DISPUTE RESOLUTION IN COURTS: EMPIRICAL STUDY ON CHALLENGES OF THE COURT-CONNECTED MEDIATION IN LITHUANIA
}

\author{
Agnė Tvaronavičienė ${ }^{1}$, Natalija Kaminskiené ${ }^{2}$, Irena Žemaitaityte் ${ }^{3}$, Maria Cudowska ${ }^{4}$ \\ 1,2,3 Mykolas Romeris University, Ateities st. 20, LT-08303, Vilnius, Lithuania \\ ${ }^{4}$ University of Bialystok, Swierkowa str. 20 B, PL-15-328, Bialystok, Poland

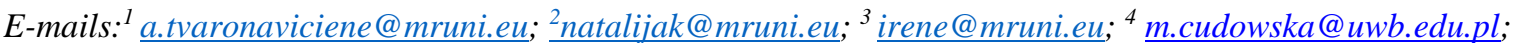

Received 29 January 2021; accepted 27 February 2021; published 30 March 2021

\begin{abstract}
Court-connected mediation designed to foster more sustainable dispute resolution practices in Lithuania was launched in 2005. The article is an elaboration on Lithuania's experiences relating to court-connected mediation in the realm of civil justice. It investigates the problem of the so called "plateau", when the number of mediated cases stops to grow, thus raising the question of what is the future of court-connected mediation in general. Authors present the main features of the Lithuanian court-connected mediation model and stages of its formation. The autors strive to provide a better understanding of the possible causes for the problem under consideration, as well as underlying assumptions associated with sustainable dispute resolution practices in courts. Next, the results of the original quantitative and qualitative empirical survey dedicated to the analyzed problem and performed by the authors in the beginning of 2021 are presented. The research is supplemented by data from Poland, which presents a fracture of the problems related to court-connected mediation in Eastern Europe. Poland's perspective provides a glance into another legal system, which chose a different model of court-connected mediation without the direct involvement of judges as mediators. Still, the data from Poland shows the tendency of a steady influx of mediated cases. The article ends with a discussion, conclussions and recommendations on the causes and consequences of mediation stagnation in the process of developing a court-mediation and, possibly, mediation in general. The paper is dedicated to dispute resolution experts, both practitioners and scientists, who are interested in Eastern European experiences and problems associated with the development of mediatiaton.
\end{abstract}

Keywords: court-connected mediation; judge as a mediator; dispute resolution; mediation "plateau"; stagnation; empirical research

Reference to this paper should be made as follows: Tvaronavičienė, A., Kaminskienė, N., Žemaitaitytė, I., Cudowska, M. 2021. Towards more sustainable dispute resolution in courts: empirical study on challenges of the court-connected mediation in Lithuania. Entrepreneurship and Sustainability Issues, 8(3), 633-653. http://doi.org/10.9770/jesi.2021.8.3(40)

JEL Classifications: K15, K41, Q01

\section{Introduction}

The court-connected mediation was a starting form of mediation development in Lithuania, which, compared to out-of-court mediation, in the last 15 years showed incredible results by high numbers of enthusiasts who decided 


\section{ENTREPRENEURSHIP AND SUSTAINABILITY ISSUES}

ISSN 2345-0282 (online) http://jssidoi.org/jesi/

2021 Volume 8 Number 3 (March)

http://doi.org/10.9770/jesi.2021.8.3(40)

to join the list of court mediators and exponentially growing numbers of mediations conducted in the court. The main intention of launching court-connected mediation went in line with a need to promote social dialog and foster settlements, as adversial litigation could not be treated as dispute resolution process bringing to sustainability (Kaminskiene et al. 2014). However, the days of glory for the court-connected mediation seem to have passed. As it is proven further, court-connected mediation in Lithuania does not appear to be popular as a preferred way of settling a dispute. In fact, during the last four years the number of the court-connected mediation cases is stable, but has shown no significant change. Currently such situation can be described as a "plateau" and requires to answer the question of what can be done to prevent such situation and even broader question of what the future holds for a court-connected mediation not only in Lithuania, but also in the countries that face the same problems of mediation stagnation.

The scientific discussion requires a glance from aside from the position of the development of court-connected mediation in another country. Thus, the article presents a short overview of Polish court-connected mediation model (without involvement of judges as mediators), which arguably shows a tendency of a stable mediation growth.

The objective of this article is to analyze the reasons for the problem of stagnation of court-connected mediation, suggest the ways for overcoming it and possible further directions for the development of court-connected mediation.

Previous research on the subject. The topic of court-connected mediation usually forms a natural part of general scientific studies on mediation, as long as the court-connected mediation is rather popular form of mediation. Nevertheless, some authors tend to debate if court-connected mediation is a part of reinvigoration or further erosion of a democratic justice system (Welsh 2004, 117). However, the works where court-connected mediation models or programs are analyzed empirically from the point of view of their problematics and effectiveness, dominate mostly in the works of American scientists, but are not so common for Europe. The works of Roselle L. Wissler (2004) presented the results of empirical researches on court-connected general civil case mediation and gave answers to the question of general effectiveness of court-connected mediation program used in the US. The lessons that are emerging from the available empirical data regarding best practices for court-connected mediation programs that mediate non-family civil matters are discussed in the article of Barbara McAdoo, Nancy Welsh and Roselle Wissler (2003). John Lande (2004) analyzed why some mediation programs produced the desired results while others did not outperform traditional litigation. Worldwide perspective is given in the works of Shahla F.Ali (2018), who explored the attitudes and perceptions of practitioners implementing court mediation programs in five regions (including Europe) of the world in order to understand the dynamics, challenges, and lessons learned from the perspective of those directly engaged in the work of administering, representing, and mediating civil claims.

In Lithuania the topic of court-connected mediation was previously analyzed by Natalija Kaminskienè (2010) (the article assesses the results of the pilot court-connected mediation project, attempts to identify problems encountered and propose possible solutions), Ieva Saudargaite (2015) (the research object is the legal regulation of judicial mediation in civil disputes in Lithuania), Agnè Tvaronavičienè and Natalija Kaminskienè (2019) (the article analyzes the application of court-connected mediation in administrative law and proposes possible improvements in the legal framework in this area). Authors Sandra Mole and Jolanta Sondaite $(2014 ; 2019)$ analyzed attitudes of court mediators toward the practice of court-connected mediation from psychological point of view. Opportunities of court-connected and private family disputes mediation were described in the work of Salomejja Zaksaite and Zigmas Garalevičius (2009). However, most of these works were published during the period when court-connected mediation "prospered" and was growing in numbers. No research was made on the 


\section{ENTREPRENEURSHIP AND SUSTAINABILITY ISSUES}

ISSN 2345-0282 (online) http://jssidoi.org/jesi/

2021 Volume 8 Number 3 (March)

http://doi.org/10.9770/jesi.2021.8.3(40)

current stagnation of the court-connected mediation in Lithuania. This study is a first attempt to perform a quantitative and qualitative empirical research dedicated to the current problems of court-connected mediation in practice.

Methodology. Research was carried out using the methods of scientific literature review, document and comparative analyses, quantitative and qualitative empirical methods.

\section{Theoretical background}

Mediation was introduced for the first time in the Lithuanian legal system in 2005 through a court-connected mediation pilot project. The project was inspired by the embedment of court conciliation, a novelty in Lithuanian civil procedure introduced in 2003 under the new Code of Civil Procedure (hereinafter referred as - CCP). The pilot project was conducted by several judges and academicians familiar with the notion of mediation, who strongly supported the model adopted by the province of Quebec in Canada and its introduction in the Lithuanian courts (Kaminskiene 2010).

Initially only one court in capital of Lithuania - Vilnius, was applying the procedure of mediation. In 2006, already several district courts were using it, and after yielding positive results, later in 2007, following the Decree of Judicial Council No. 13P-15, it was extended to all Lithuanian courts. Within just a few years the pilot became the permanent court-connected mediation program in civil cases throughout the country.

The choice of starting mediation from the courts was mostly influenced by understanding that people of Lithuania recognize the authority of the court and trust judges. That is why it was decided that the best person, who could reliably offer mediation to the parties without discrediting himself, should be a judge.

Thus, successful experience in the Canadian province of Quebec has been applied in the development of the court-connected mediation project in Lithuania. Even nowadays the Lithuanian and Quebec models of courtconnected mediation have much in common. For example, it similarly provides for the possibility of private meetings between the parties to the dispute and the mediator, the persons involved in court-connected mediation, the principle of confidentiality etc. However, as the time has passed, some new features were adopted to allow court-connected mediation operating more effectively.

Since the start of the pilot project court-connected mediation in Lithuania was completely voluntary. However, from 2019 in separate cases following the discretion of the judge, parties to a dispute may be referred to mandatory court mediation (CCP Art. 231 $\left.{ }^{1}(1)\right)$.

Initially, court-connected mediation was performed by a court-appointed mediator included in the list of court mediators administered by the National courts administration. Court mediators were listed since the very beginning of this institute. By the end of 2018 there were more than 450 mediators in the list of court mediators and this number was still growing. 81 per cent of all listed court-mediators were not judges - advocates, lawyers, psychologists, social workers, etc. Interestingly, although only 19 per cent of court mediators were judges, most of court mediations were mediated by court mediators-judges. Namely, 87 per cent of civil cases in 2018 were mediated by judges-mediators and only 13 per cent by non-judges (Annual Report of Lithuanian Courts 2018).

However, since 2019 only judges are allowed to be called "court-mediators" and be included into the list of court mediators (Law on Mediation, Art. 23, part 2). Currently there are 105 court mediators-judges in the list (The list of Court Mediators 2021). Trained judges serve as court mediators, whilst other mediators may be appointed from 


\section{ENTREPRENEURSHIP AND SUSTAINABILITY ISSUES}

ISSN 2345-0282 (online) http://jssidoi.org/jesi/

2021 Volume 8 Number 3 (March)

http://doi.org/10.9770/jesi.2021.8.3(40)

the general Republic of Lithuania list of mediators only if a judge-mediator is not available due to objective reasons.

From the start of the court-connected mediation in Lithuania, if the judge wished to direct the case to mediation, he had no possibility to mediate the case himself and had to forward the case to another mediator nevertheless the judge had the status of mediator himself. However, since 2018 a judge-mediator under the parties' consent acquired the right to mediate even in cases where primarily had acted as a judge under the consent of the parties (CCP Art. 231 ${ }^{1}$, part 2). Where a successful settlement was reached, such a judge-mediator could confirm the settlement agreement by the ruling. If the mediation was unsuccessful then another judge had to be appointed to further examine the case from its very beginning.

After the recent legislation changes, court mediation is a natural part of civil procedure. Nowadays the courtconnected mediation process in Lithuania is carried out according to the regulations of the Law on Mediation, the $\mathrm{CCP}$ and the Rules on Court Mediation. Court-connected mediation services are provided free of charge.

Court mediators have special requirements to attain their status: if a judge has more than three years of practice, he needs only 16 hours of mediation training and does not have to take an exam. Other mediators in order to be included into the Republic of Lithuania list of mediators need to have 40 hours of mediation training and to take an exam. Only judges that have less than three years of practice have to follow such general requirements. The procedure for the improvement of qualification for those mediators who are judges is determined by the Council of Judges.

The progress of court mediation in civil cases during the last 8 years in Lithuania is significant and is depicted in Chart 1. In terms of effectiveness of court mediation in Lithuania, the results of court mediations show that a bit less than a half (47 per cent) of court mediations are completed by settlement (Annual Resport of Lithuanian Courts 2019).

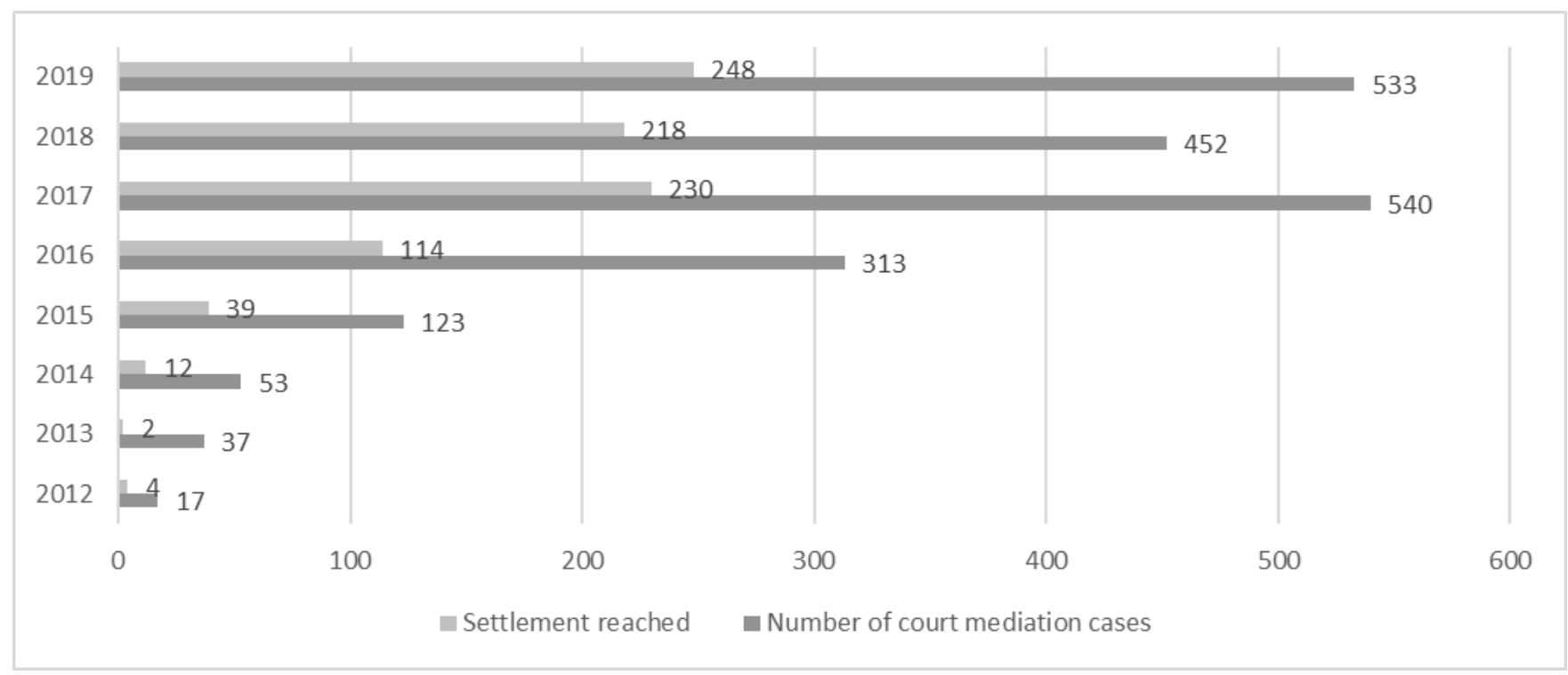

Figure 1. Number of court mediations in Lithuania from 2012 to 2019, and their effectiveness 


\section{ENTREPRENEURSHIP AND SUSTAINABILITY ISSUES}

ISSN 2345-0282 (online) http://jssidoi.org/jesi/

2021 Volume 8 Number 3 (March)

http://doi.org/10.9770/jesi.2021.8.3(40)

However, the amount of court mediations compared to the overall workload of civil cases in the court of the first instance in Lithuania is miserable. According to the latest data, 159655 civil cases were started in courts in 2019, yet there were only 533 mediations in civil cases during the same period.

Thus, court mediation does not appear to be popular as a preferred way of settling a dispute. In fact, during the last four years the number of the court-connected mediation cases is stable, but has shown no significant change.

\section{Research Methodology}

A mixed research strategy was chosen for the study, combining quantitative and qualitative research approaches, thus ensuring a comprehensive approach to data collection. The quantitative part of the research provides an opportunity to analyze court-connected mediation in Lithuania. The aim of the qualitative research is to focus on the experience of the research subjects (judges and judges-mediators) in order to study the current problems of court-connected mediation in Lithuania, the attitude of court management and colleagues of judges towards mediators and their activities.

The tool of quantitative empirical survey is a questionnaire. The prepared questionnaire consists of 20 questions. 90 respondents participated in the survey. Data analysis was implemented by the application of descriptive statistics.

The focus group method was chosen for the qualitative research, gathering reflections of the research participants on their work experience (Morgan, 2010). 5 judges and 5 judges-mediators ( 6 women and 4 men) from different Lithuanian courts were involved in the study. The study data was documented by recording. Oral consent of the survey participants was obtained before recording the data. The audio recordings of the discussions were studied, participants`contributions to the discussions were transcribed. The research data was analyzed, interpreted and conclusions were drawn. Thematic analysis was used for data analysis.

Research ethics. The research was conducted in accordance with the requirements of research ethics. The questionnaire was posted on Google forms. Research participants took part in the survey on voluntary basis. In order to ensure the anonymity of the respondents and the confidentiality of the provided answers, the principle of secrecy was followed (Gaižauskaite, Mikienè, 2014). The survey participants were introduced to the aim of the survey and the method used. Researchers presented the purpose of the research, the course, data recording, ethical issues: the principle of ensuring confidentiality and anonymity.

\section{Quantitative research results}

Quantitative research results reflect a favorable attitude of judges working with civil cases in the Republic of Lithuania to court-connected mediation, but also signals some of the challenges currently faced by the system.

64 judges and 26 judges-mediators (90 respondents in total) took part in the quantitative research. There were about 70 women and 18 men among the surveyed judges and judges-mediators. A few of the participants did not want to reveal their gender. In regards to age, the respondents are almost evenly distributed in groups aged between 31 and 40 ( 22 respondents), 41 and 50 (31 respondents), and 51 and 60 (28 respondents). Only 9 respondents made up the "60 and over" age group. The majority of judges and judges-mediators who took part in the survey (40 respondents) have over 15 years of work experience as judges. 22 respondents have up to 5 years of work experience as judges and 29 respondents have between 6 and 15 years of experience. Most of the surveyed judges work in courts around Vilnius region (31). Slightly fewer of them work in Kaunas (25) and Klaipeda (16) regions. The least of the participants who responded were from Šiauliai (9) and Panevėžys (8) 


\section{ENTREPRENEURSHIP AND SUSTAINABILITY ISSUES}

ISSN 2345-0282 (online) http://jssidoi.org/jesi/

2021 Volume 8 Number 3 (March)

http://doi.org/10.9770/jesi.2021.8.3(40)

regions. The vast majority of all judges (48) and judges-mediators (21) surveyed use court-connected mediation relatively rarely in their daily practice (up to 5 cases per judge in 2020). The largest number of judges-mediators surveyed indicated that in 2020 they mediated up to 5 cases (13 respondents), 6 respondents mediated between 6 and 15 cases. 6 respondents indicated that they provided court-connected mediation services more than 15 times.

\subsection{General assessment of court-connected mediation practice in Lithuania}

In the Republic of Lithuania amongst judges of civil cases the attitudes regarding the system of court-connected mediation are generally positive. The chart below shows that as many as 30 judges surveyed (47\%) have no doubts about it at all. 21 other judges chose the answer "Rather positive than negative". 10 judges remain neutral regarding this issue. Although none of the respondents assessed the practice of court-connected mediation negatively, it is clear that a sufficiently large portion of the judges who have assessed the system "rather positively than negatively" see the shortcomings of court-connected mediation that need to be resolved in order to further develop this institute. More satisfaction with the benefits of court-connected mediation amongst judges would also mean its wider promotion to litigants during legal disputes.

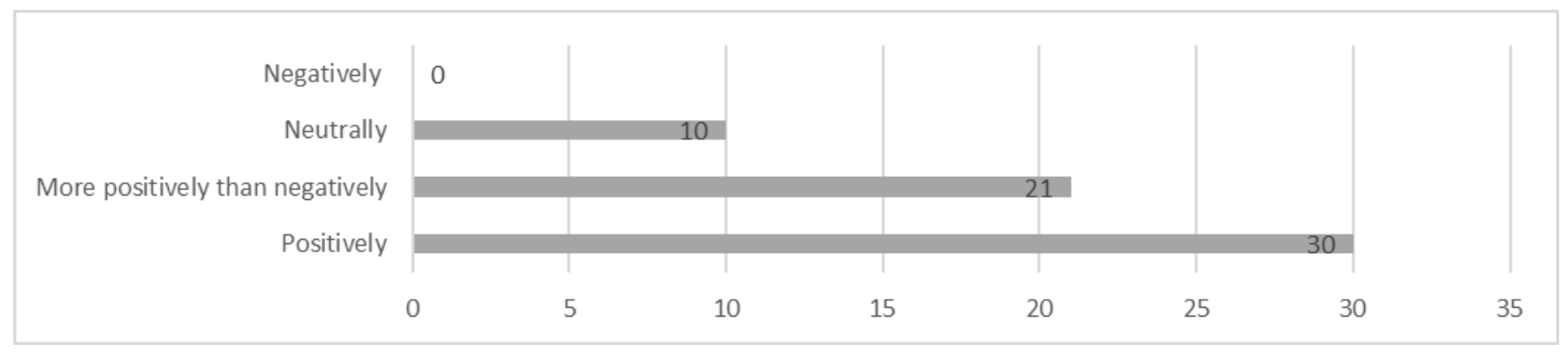

Figure 2. Evaluation of Court-connected Mediation (Perspective of the Judges)

The researchers have posed a similar question regarding the evaluation of the court-connected mediation system in Lithuania to the judges-mediators. The same trend of positive evaluation of court-connected mediation was observed among judges-mediators. However, there were several judges-mediators, who viewed the system negatively, thus attracting the attention of the researchers. The ideas of these judges were further investigated in the qualitative research.

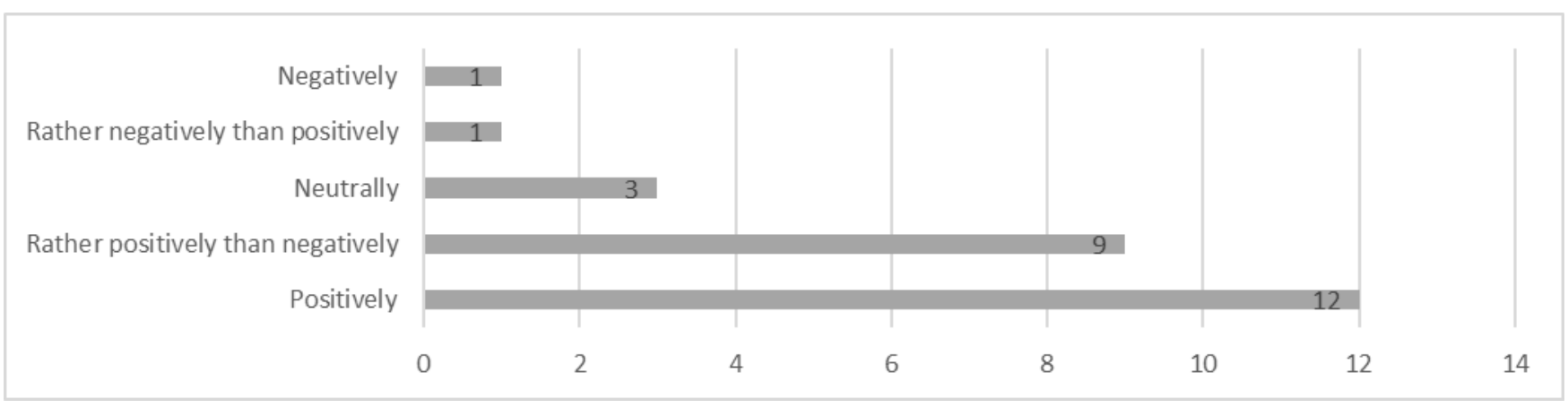

Figure 3. Evaluation of Court-connected Mediation (Perspective of the Judges-mediators)

When asked about the obstacles faced by the institute of court-connected mediation in Lithuania, the judges were asked to choose their answer from 8 options proposed by the researchers. They were also given the opportunity to share their own thoughts and ideas on the matter. 


\section{ENTREPRENEURSHIP AND SUSTAINABILITY ISSUES}

ISSN 2345-0282 (online) http://jssidoi.org/jesi/

2021 Volume 8 Number 3 (March)

http://doi.org/10.9770/jesi.2021.8.3(40)

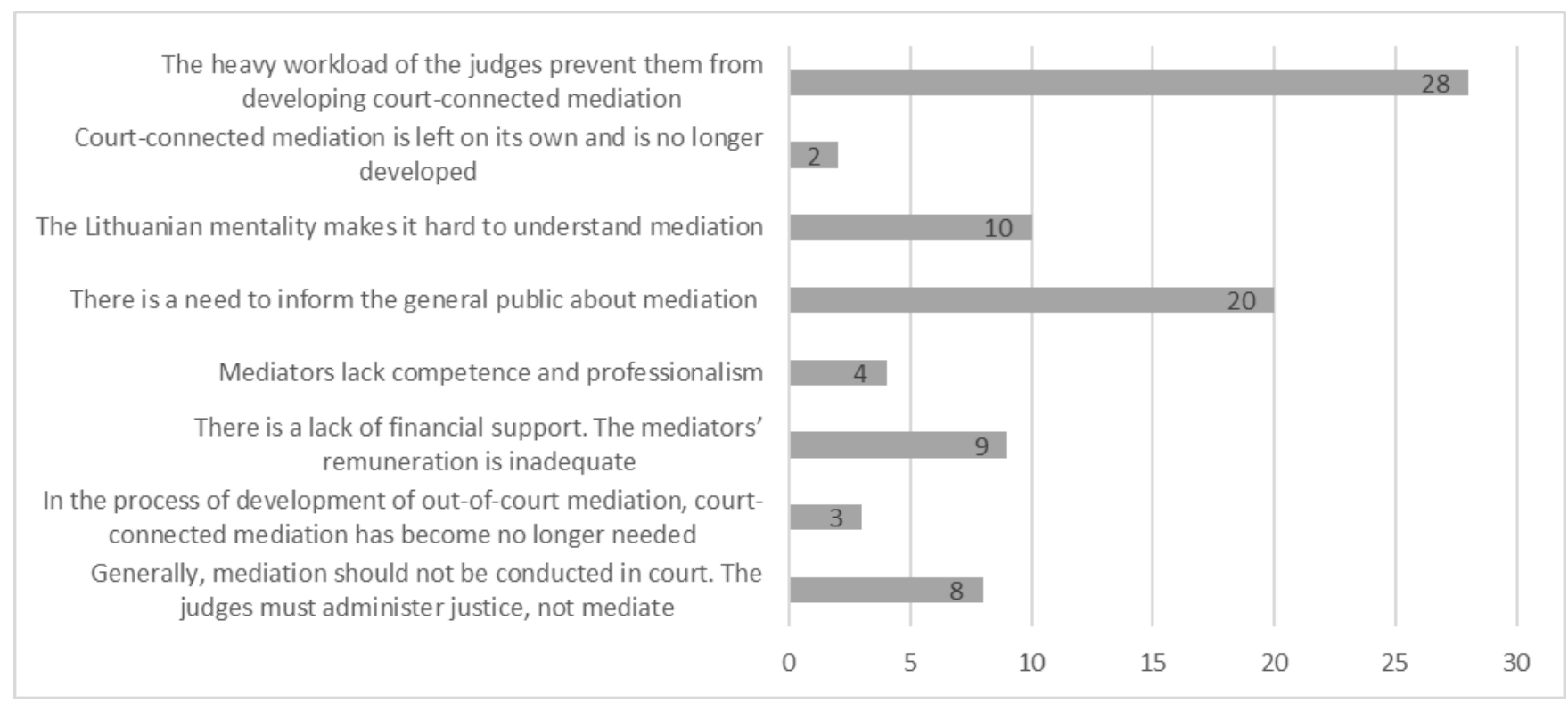

Figure 4. Obstacles Faced by the Court-connected Mediation (Perspective of Judges)

The surveyed judges outline excessive workload (28), insufficient public information (20), peculiarities of Lithuanian mentality (10), inadequate reward system (9) and the assumption that judges must administer justice, not mediate (8) as most significant obstacles to the development of court-connected mediation in Lithuania. 8 judges shared their own ideas regarding the issue. 1 judge expressed his oppinion that Lithuanian courts are encouraged to resolve cases as quickly as possible and that is opposite to aiming for peace. The judge noted that "currently, the priority given to the speed of proceedings over the restoration of legal peace is an obstacle to pursuing mediation more frequently." Another judge highlighted the inadequacy of judges-mediators' working conditions. He has commented that "the basic working conditions are not ensured to judges-mediators. No premises are provided. It is often up to the mediator to plan and decide where the mediation will take place. Due to inadequate evaluation of their work (more precisely, undervaluation) and high workload, they often refuse to pursue mediation". Another judge supported this idea, stating that "the parties only trust judges-mediators, but they have no interest in pursuing mediation." Interestingly, the concerns of judges regarding the working conditions of judges-mediators are only partially in line with the judges-mediators' own concerns. The majority of the surveyed judges-mediators (16 out of 26) said that they were satisfied with their working conditions as court mediators. Only 8 of them expressed dissatisfaction. One of the surveyed judges-mediators did not provide a clear answer on that matter.

When asked the same question about obstacles to the development of court-connected mediation, judgesmediators draw very similar conclusions. 


\section{ENTREPRENEURSHIP AND SUSTAINABILITY ISSUES}

ISSN 2345-0282 (online) http://jssidoi.org/jesi/

2021 Volume 8 Number 3 (March)

http://doi.org/10.9770/jesi.2021.8.3(40)

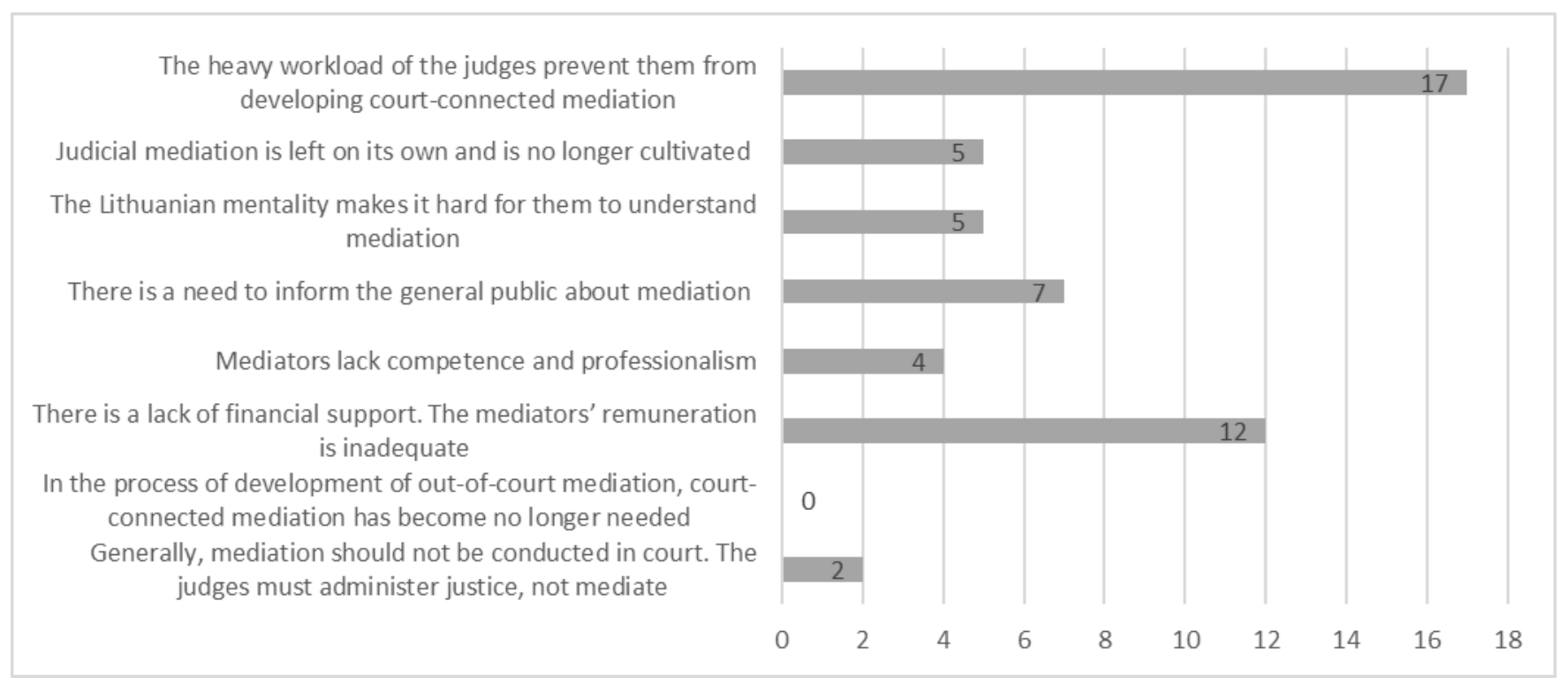

Figure 5. Obstacles Faced by the Court-connected Mediation (Perspective of Judges-mediators)

17 judges-mediators believe that one of the main reasons why the development of court-connected mediation has stopped is the excessive workload of judges. However, such opinion of the majority is not unanimous. One or the respondents stated that "judges mediate voluntarily, on their own initiative, and their workload should not be an incentive for mediation, it is the result of a goodwill, judges choose to engage in mediation without any coersion, thus, the workload of mediators should not be reduced because in that case they would receive significantly less cases than their colleagues". 12 judges-mediators believe that an important obstacle is the inadequacy of the reward system for court mediators. According to the surveyed judges-mediators, lack of information of the public on mediation is another important obstacle for futher development of court-connected mediation. Several judgesmediators identified more reasons that preclude court mediation, which were not provided in the list of the answers suggested by the researchers. One judge-mediator stated that "there is a lack of understanding and support on the part of self-governance of courts, court presidents and fellow judges".

\subsection{Evaluating the effectiveness of measures to promote court-connected mediation}

\subsubsection{The right to mediate in "your own" case}

In order to promote court-connected mediation, it is established in part 2 of Article $231^{1}$ of the CCP that with the consent of the parties a judge-mediator has a right to mediate a case for which he or she has been appointed as a judge (the so called "own case"). Judge-mediator is also entitled to approve a settlement agreement reached during court-connected mediation, but in the case of a failed mediation, it is prohibited for the same judgemediator to continue to hear the case. In order to assess the effectiveness of this provision, judges-mediators were asked to answer the question of how many of "their cases" they have mediated by themselves. The responses indicated that as many as 21 out of 26 surveyed mediators did not provide court-connected mediation services in their "own cases", which raises the question of the effectiveness of the legal norm providing the right for judgesmediators to mediate in their "own cases". This opinion was further investigated in the qualitative research. 


\section{ENTREPRENEURSHIP AND SUSTAINABILITY ISSUES}

ISSN 2345-0282 (online) http://jssidoi.org/jesi/

2021 Volume 8 Number 3 (March)

http://doi.org/10.9770/jesi.2021.8.3(40)

\subsubsection{Mandatory court-connected mediation}

Throughout the course of quantitative research, one of the goals was to investigate the opinion of the respondents on the idea of establishing mandatory court-connected mediation. Since 2017, part 1 of Article $231^{1}$ of the CCP stipulates the possibility for a judge or a panel of judges to prescribe to the parties a compulsory court-connected mediation in the event of a high probability of a settlement. The purpose of this provision is to increase the usage of the court-connected mediation. Results of the study show that this form of compulsory mediation (judge's discretion) does not work in practice. Judges are not inclined to exercise this right widely. As many as 52 judges (more than 81\%) indicated that they had not exercised this right. Only 11 judges indicated that they had exercised this right in their practice. Most of them only once. Only 3 respondents indicated that they had applied this provision 3,5 and 6 times.

When asked about the reasons for not exercising this discretion, the judges could choose one or more of the answers offered to them by the researchers. Most of the judges (30) indicated that the disputes they dealt with were not suitable for compulsory mediation. 9 judges chose the option stating that "I think this is incompatible with the idea of mediation". 6 judges chose the option "I usually want the case to be heard as soon as possible and mediation prolongs the process". 2 judges stated that there is no such practice in their court. One judge admitted that he was not even aware of such possibility. The judges were also given the opportunity to share their own views on application of this provision. Those, who expressed their own opinion, emphasized the importance of the principle of voluntary mediation (e. g. "Essential principles of mediation - voluntary grounds. A party may withdraw from mediation at any time. If a party does not agree to mediation from the very beginning, mediation is not possible, unless that position changes in the process"; "The parties must agree to pursue mediation, otherwise, one will not force the parties to seek a solution", etc.). An interesting idea was also raised about the incentive effect of mandatory court-connected mediation. One judge stated that "it is enough to say that the court can order compulsory mediation and the parties themselves agree and no longer need to be ordered to pursue mediation." Another judge emphasized the time that compulsory mediation will take ("After the order of compulsory mediation and the possible withdrawal of the party, there will be a loss of at least two months in time. The length of the proceedings will extend."). Another judge stated "I do not believe in the efficiency of this institute. In all of my cases the parties themselves withdrew from mediation."

In order to determine the judges' knowledge about suitability of mediation for the cases, they were asked "What criteria do you consider when referring cases to compulsory court-connected mediation?" Since only those judges who had applied mandatory court-connected mediation in their practice were asked to answer this question, few answers were received. However, they are important in order to determine the level of knowledge of judges in this area. Respondents were able to choose from 6 answers proposed by the researchers. 


\section{ENTREPRENEURSHIP AND SUSTAINABILITY ISSUES}

ISSN 2345-0282 (online) http://jssidoi.org/jesi/

2021 Volume 8 Number 3 (March)

http://doi.org/10.9770/jesi.2021.8.3(40)

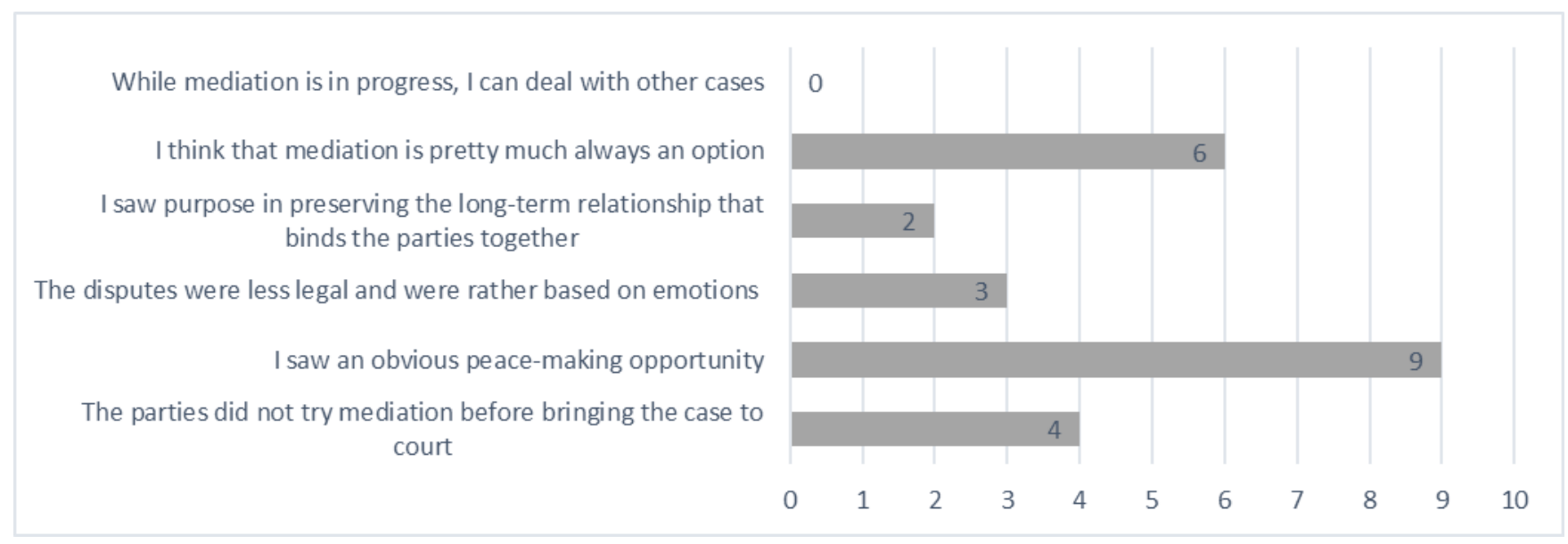

Figure 6. Criterias for the application of mandatory court-connected mediation (Perspective of Judges)

The diagram above proves that usually the reason why judges direct the parties to mandatory court-connected mediation is the probability of concluding a settlement (9) in the case. 6 judges indicated that they believe that mandatory mediation can be applicable in all disputes. Only 4 judges chose the answer related to the fact that there was no mediation pursued between the parties before the case was brought to court. Even fewer judges, 3 and 2, highlighted the importance of the longevity of the relationship and the strength of the emotional background of the case, which is often indicated as the most important criteria for the applicability of mediation.

4.2.3. The knowledge of judges in determining whether a dispute is appropriate to be referred to the mandatory court-connected mediation

When asked about their knowledge in determining whether a dispute is appropriate for mandatory referral to court-connected mediation, judges were quite positive about it. As many as 46 percent of respondents (29 judges) indicated that their knowledge was excellent. Just as many rated their knowledge as average. 4 judges identified a lack of such knowledge and only 1 admitted to having no such knowledge at all.

In search of the reasons why the number of court-connected mediation cases has not been growing as fast as before in the recent years, the researchers hypothesized that it could have been affected by the new provisions of the Law on mediation, which came into force in 2020 and established mediation as a mandatory pre-trial stage for resolving family disputes. The judges were asked whether they offer court-connected mediation to parties in family disputes who had already resorted to compulsory mediation before the case was brought to court. Unfortunately, the hypothesis was not confirmed. 28 of the judges stated that the decision regarding the offer of court-connected mediation is based on the nature of the dispute and its parties, and the fact that the parties have already tried to pursue mediation does not have much influence on the decision. 24 judges indicated that they offer court-connected mediation even to those parties who tried mediating their dispute before the case was brought to court and only 6 judges said that in such a situation the parties are no longer offered court-connected mediation.

In conclusion, it is clear that some of the measures that were initially intended to promote court-connected mediation have not produced the expected results. It is recommended to pay more attention to training judges in the field of mediation, especially regarding the knowledge on when the dispute is mostly advisable to refer to court-connected mediation. 


\section{ENTREPRENEURSHIP AND SUSTAINABILITY ISSUES}

ISSN 2345-0282 (online) http://jssidoi.org/jesi/

2021 Volume 8 Number 3 (March)

http://doi.org/10.9770/jesi.2021.8.3(40)

\section{Qualitative research results}

\subsection{General assessment of the court-connected mediation practice in Lithuania}

Qualitative research data analysis revealed that both judges (J) and judges-mediators (JM) assessed courtconnected mediation positively. Court-connected mediation is an opportunity to find a solution acceptable to both dispute parties and to resolve the dispute peacefully. "Social peace is the settlement of a dispute when both parties reach an agreement, which is a great good, at a state level, at a society level, at family, business or partner levels" (J3); "it is only good, <... in any case, any level of peace, is far better than a hostile, long war between the parties. They themselves agree on the terms, <...> both parties leave the court as winners ... and both parties are satisfied" (J4).

Both judges and judges-mediators agree that a considerable amount of attention is paid to court-connected mediation. Judges who deal with civil cases always inform the parties to the dispute about mediation, they ask the parties whether substantial efforts have been made to resolve the dispute peacefully. According to the respondents: "In each case we suggest that the parties try to negotiate and to find a peaceful solution by themselves, if that is possible" (J4); "In practice, it is likely that when dealing with cases all judges will suggest to seek peaceful dispute resolution" (J2). However, as noted by the participants of the study, it is important that parties themselves want to resolve the disputes peacefully.

All participants of the research agreed that mediation is currently widely known. The judges mentioned that there are cases where the parties themselves request mediation and even indicate a preferred mediator. In some cases, even those parties that do not have lawyers, who would ensure that they are made aware of mediation as a possibility, have heard of mediation before. Perhaps they have heard about successful cases of mediation. The judges say that "when we accept lawsuits, along with the documents we send to the parties information about court-connected mediation, and we actually suggest it during the hearing. <... $\rangle$ we often manage to persuade the parties $<\ldots>$ they decide to try out the suggested path. We stress that it does not necessarily mean that you will reach an agreement in the end, but it is very important for you to talk, it might make it easier for you in the future" (J1). According to judges-mediators, court-connected mediation received more attention a few years ago. It used to be more publicized and was discussed in the legal community more frequently. One of the participants of the research pointed out the recent lack of information about court-connected mediation and the suppressed publicity process, but she noted that the "work has already been done" (JM2) and the mediation institute simply no longer needs to be repeatedly introduced to the public. "It is likely that mediation does not need that much advertising, that much attention, that much publicizing, because one can already see that the process is smooth and it is in force at full speed" (JM5).

However, the respondents acknowledged the fact that some of their fellow judges' views are quite formal when it comes to the promotion of the court-connected mediation. They simply inform the parties to the dispute that they have a right to pursue mediation, but do not actively encourage or persuade them to exercise the right. On the other hand, there are judges who are not judges-mediators themselves, yet they make extensive work to offer the court-connected mediation in their cases giving the dispute parties every opportunity to seek peaceful settlement. "I am convinced that there are judges who carry out mediation in their "own cases" by actively suggesting ways to reach a peaceful settlement, perhaps even some specific solutions, doing that [more actively] than the judges who are dealing with those cases" (J5).

The respondents noted that to this day court mediators still lack attention. According to them, both the court administrators and the National Courts Administration should pay more attention to judges-mediators. Participants of the research stated that "everyone here has an interest in publicizing this process, which is indeed extremely necessary and important" (JM1); "Mediators really lack attention, but not in the literal sense - 


\section{ENTREPRENEURSHIP AND SUSTAINABILITY ISSUES}

ISSN 2345-0282 (online) http://jssidoi.org/jesi/

2021 Volume 8 Number 3 (March)

http://doi.org/10.9770/jesi.2021.8.3(40)

mediators may lack help" (JM3). Judges-mediators reminisced that they decided to engage in mediation because it was something new and interesting. When they started carrying out court-connected mediation, they saw great meaning and purpose in promoting such a peace-building-oriented procedure in court. "It was something new, and answering the question "why am I still engaged in mediation?", it seems that most of us who have tried it out and have seen positive results are encouraged by them and still think we can do the job and take on those additional responsibilities" (JM3). Yet at the same time, it was mentioned that besides building and extending the community of court mediators, it is also important to maintain the motivation of existing mediators, who, unfortunately, often drop out due to overwork or lack of knowledge and skills. "To a certain point, you can take the ideological path, the motivation is somewhat driven on an ideological basis. But then those human psychological effects make you stop and you begin to lack motivation" (JM5); "On the other hand, when you engage in an extracurricular activity, you take extra interest in it. It is only natural that your horizon expands and you see that there is room for improvement, that there is something to learn and more knowledge is required" (JM3). The respondents noted that "a great deal of training is directed at a circle of individuals who are only to be provided that mediator qualification. But for existing mediators, improving those skills, not forgetting and remembering both the legal regulations and other skills - I personally lack such training" (JM4).

\subsection{Obstacles to the development of court-connected mediation in Lithuania}

When asked to share their insights about why they think the number of court mediations has stalled, the members of the focus group identified a number of reasons: a) there is a certain distrust in colleagues ("If I will pass on the case to my colleague, he will mediate it, he might succeed, but he might also fail, he might give it back, then I will still have to deal with the case and I might even get another one because his schedule will be full and the courts are small") (J5), b) the ability of people to negotiate peacefully is not sufficiently developed ("We must cultivate our cultural aspect. That understanding, the trust in both the institute of mediators, and any other common ability to negotiate peacefully. Because everyone here in Lithuania tends to curse at the courts anyway, but judging from the number of cases it is clear that they still want to go to those courts rather than to solve their disputes by themselves") (J5). As for the reason why the number of court mediations is no longer increasing, one participant noted that c) the number of civil cases in Lithuania has been decreasing throughout the last few years. Besides, litigation cases at first instance, especially in large cities, often consist of cases that are settled in absentia without the presence of litigants, so there is no possibility to offer mediation ("The big Lithuanian courts $\langle\ldots>$ make such decisions very frequently, which means that the defendant is very passive, he does not participate, so there is no point in talking about mediation in this case at all. It is now a question of whether it is possible to increase the frequency [of mediations], it should be possible. If things were more active, people would be educated, fellow lawyers would look at mediation more favorably and encourage their clients to pursue it, then I think we could have that kind of growth") (J1). Another reason why the number of court-connected mediations stopped growing, according to the focus group, is d) the duration of ongoing cases. The courts, just like the parties to the disputes, have an interest in resolving cases in the shortest possible time, and referring the parties to court-connected mediation will undoubtedly prolong the duration of the proceedings. Moreover, there is no guarantee that mediation will succeed. In the absence of a peaceful settlement, the dispute is returned back to the court for further hearing, which statistically means that the duration of the case hearing will be longer than average. "We have a very clear orientation towards a short trial. This becomes one of the criteria - that we have to deal with cases in the shortest possible time. Mediation is immediately perceived as some additional pause in the proceedings. Therefore, we are more likely to suggest for the parties to attempt to reach a peaceful agreement independently, we give them a couple of weeks before the next hearing to try and such a model is preferred over sending the case to mediation." (J5). "Let's say that some judges may be hesitant to refer the case to courtconnected mediation, because if mediation fails, the overall time limit for hearing the case will be prolonged. And, of course, mediation usually takes a few months, it can take a long time and in case of failure, statistically for the judge it will take longer to process the case. I myself was surprised by such arguments and I think maybe we could think of some leverage points here, to deduct the amount of time that the mediation takes from the 


\section{ENTREPRENEURSHIP AND SUSTAINABILITY ISSUES}

ISSN 2345-0282 (online) http://jssidoi.org/jesi/

2021 Volume 8 Number 3 (March)

http://doi.org/10.9770/jesi.2021.8.3(40)

length of the case or something like that because I myself have not even thought that there may be such fears" (JM4).

During the investigation both the judges and the judges-mediators touched upon the subject of a workload relevant to both of the groups as the number of new cases for judges-mediators conducting court-connected mediation is reduced to some extent. "If mediation is ordered, some of our cases are taken away" (JM5). Although there is currently no clear regulation on reducing the number of cases for judges conducting courtconnected mediation, this issue is causing some dissatisfaction and tension among other judges in courts. " $<\ldots>$ we are saying that the workload is heavy and we have some judges who, for example, count their workload including [out-of-court mediations] and thus deal with fewer cases" (J5). Judges lack clearer information from the National Courts Administration. "At the moment, we cannot see how much of our workload is made up of mediation cases, it is impossible ... we have not yet done so. We have also contacted the National Courts Administration asking them to explain to us the weight of a mediation case and what it affects" (J4). However, judges themselves agree that when talking to fellow judges-mediators, they say they do not feel any significant reduction in workload and they often refuse to take mediation themselves because it is not worth it for them to mediate in terms of a workload. They prefer choosing to hear the ordinary case and to then have a clear sense of their workload. "They are formally court mediators, they are on the list, but they don't take a single case. They say, they would rather take the case assigned to them, then at least their work will be formally considered a part of their workload" (J1).

\subsection{Measures to promote court-connected mediation}

Referring to part 1 of Article $231^{1}$ of the CCP that grants the judges the right to refer the parties to mandatory court-connected mediation, the judges indicated that this legal norm is useful in promoting mediation. Some respondents mentioned that they make little use of it, but the fact that such a statutory provision exists in general is perceived positively. However, it was emphasized that court-connected mediation is used to end the dispute on peaceful terms. The parties to the dispute can only participate in this process voluntarily and they themselves must be determined to resolve the dispute peacefully. "If it is a settlement, it is the will of both parties, the goodwill of both parties. And if the parties do not see the possibility for this peaceful settlement to eventually be reached, then it is obviously possible to encourage it or to somewhat persuade them, but the peace treaty still is $<\ldots>$ a reciprocal element of voluntary goodwill and concessions of both sides" (J4). "For example, I have a hard time imagining a judge, at least myself, forcing a party into mediation, because to me mediation seems to be based on voluntary principles, and if you can not convince the parties, you can not be good by force" (J1). Several other judges agreed with the provisions of part 1 of Article $231^{1}$ of the CCP on the appointment of mandatory court-connected mediation, but they also expressed doubts about the application of this norm. "I would like to mention that in any case, during the court hearing the judge can speak quite reservedly about both the possibilities or consequences of the settlement agreement and the referral of the case to mediation. Perhaps the judge is trying to avoid being accused of bias and so although he sees a high probability of resolving the dispute in peace, he cannot directly express that to the litigants at the court hearing" (J2). "If we say that this is a mediation process and it is not an integral part of the trial, then I think I have the right and reason to expect to be entitled to a legal protection instead of some alternative means of dispute resolution when I go to court" (J3). Thus, the respondents are cautious about making the appointment of court-connected mediation mandatory, as they believe that court-connected mediation is effective only when it is voluntary and when the parties are motivated to seek peace.

Judges-mediators expressed doubts about part 2 of Article $231^{1}$ of the CCP. "With the consent of the parties, judges dealing with civil cases may decide to conduct mediation themselves if they are mediators." One judgemediator shared his experience: "At the very beginning, the institute took time to establish itself and I have even had to go to such extreme situations, <...> that I had to mediate in my "own cases" (JM5). But now it can be 


\section{ENTREPRENEURSHIP AND SUSTAINABILITY ISSUES}

ISSN 2345-0282 (online) http://jssidoi.org/jesi/

2021 Volume 8 Number 3 (March)

http://doi.org/10.9770/jesi.2021.8.3(40)

concluded that it seems that the judges-mediators have a mutual agreement not to mediate their "own cases". Since in the absence of a peace agreement, the judge would have to step down and transfer the case to another judge, which would again be related to the judges' workload, the mediating judges inform the dispute parties about the possibility of mediation and, with their consent, refer the case to another mediator. "When mediators with complex cases agree to mediate them, in case of a failure, they have to withdraw from the case as judges" (JM3); "Everytime I encourage the parties to use mediation, I don't even raise the question of my candidacy, I suggest considering another mediator aside from the judge and the opportunity to go to another court" (JM4).

In civil cases court-connected mediation can legally be performed by all mediators from the List of Mediators of the Republic of Lithuania who have signed agreements with the state-guaranteed legal aid office. However, the analysis of the research data revealed that both the judges and judges-mediators believe that the people involved in the court process often want the judges to perform mediation. Not only do they associate this with the judges' extensive knowledge of legal issues, but also with their authority placing great confidence in them. One of the respondents stated that "Whenever court mediation is required and the parties come to choose mediators, judgesmediators are prioritised. This is precisely what is shown by the fact that judges are probably trusted more than other specialists who may be more qualified when it comes to settling real disputes" (J2). However, a part of the judges who participated in the research are still in favor of court-connected mediation being carried out by specialists who are not necessarily judges. In their view, a mediator should be a separate profession, especially considering the fact that professionals in this field are already being trained. "I am categorically against the participation of judges in the mediation process, categorically. When we talk about lawyers, notaries, prosecutors, we always say it is a job. When we talk about mediators, we also say that it is a job. I understand that judges have authority, I understand that they have legal knowledge, I understand that if they have worked, then [they also] have knowledge about communication and psychology, and so they can mediate. But if professional mediators were to be trained, they would do no worse" (J3). "If the system really succeeded in producing professional mediators who would have a genuine interest in resolving those disputes peacefully, I think that judges could really relinquish that function" (J1). According to an opinion of the majority of the respondents, judges should focus on the performance of their direct functions. Their functions - the administration of justice - cannot be performed by anyone else, thus, this must be the basis of their activities. Since the enforcement of court-connected mediation is not a function exclusive to the courts, judges should only refer the parties to the dispute to court-connected mediation, but not to perform mediation themselves. The respondents, who emphasized this idea, pointed out that: "I would rather have judges abstain from being court mediators all together. That is the position I take, since after all court mediation is not a court-connected function" (J2); "I would agree $<\ldots . .>$ it is not entirely a court-connected function. We are currently carrying it out, because we are generally trying to promote this institute. More often people themselves choose judges-mediators, this is probably just how the system is at the moment" (J1); "I think that the judge's contribution to courtconnected mediation should be limited to explaining to the parties [the possibility of pursuing mediation] and directing them to court-connected mediation, but not carrying it out" (J2).

In the opinion of both the judges and the judges-mediators, judges were very important in the initial stages of publicizing court-connected mediation. "Once it [court-connected mediation] has been introduced to the public, it is questionable whether we [judges] are very necessary" (JM5); "As far as I know, according to the established regulations, judges in Latvia and Estonia cannot be mediators. In that case, if our mission was to start this process, then I agree that we may have already achieved that" (JM3).

While sharing their visions of the future of court-connected mediation, members of the focus groups acknowledged that only a small part of all court disputes are resolved through mediation at the moment, therefore, there is room for growth. The respondents noted that court-connected mediation is especially effective when solving disputes of a complex nature. "I order about two or three complicated cases to be mediated a year. And as a rule of thumb, they were all resolved peacefully. The mediator would work for a long time, for as long 


\section{ENTREPRENEURSHIP AND SUSTAINABILITY ISSUES}

ISSN 2345-0282 (online) http://jssidoi.org/jesi/

2021 Volume 8 Number 3 (March)

http://doi.org/10.9770/jesi.2021.8.3(40)

as a year. The disputes are complex in nature; therefore, I am happy to know that the people have achieved a better result after mediation compared to any possible outcome that could have been achieved in court" (J1). Both the judges and the judges-mediators agree that the success of mediation lies in the results achieved and not the statistics. "If every case we refer to mediation ended peacefully, the results would be absolutely fantastic" (J1); “< ..> I am really grateful for my fellow mediators who return a successfully mediated dispute" (JM3). The participants of the research suggested that it would be wise to establish mediation as a mandatory pre-trial stage of dispute resolution in all disputes that are being settled by litigation in the CCP. This way, an even larger part of the public would learn about and experience the benefits of mediation. On the other hand, one judge pointed out that "the efforts made [to promote court-connected mediation] are very good, but there is still a need to seek balance. To what extent do the results of the mediation process correspond with those efforts and the funds that are allocated to achieve this goal?" (J3).

\section{A Different Approach Towards Court-connected Mediation: Polish Perspective}

The modern notion of mediation has been introduced into the polish legal system through the Polish Code of Civil Procedure in 2005 (further - Polish CCP). Through simplifying the law, and safeguarding due process rights of litigants, mediation was a process designed to support the processing of service of justice, rather than to serve as an alternative to it. First, as part of the simplification process, mediation settlements were granted the same legal significance as court ordered judgments. Second, civil disputes that could be disbursed through a court settlement would fall under a category of disputes prone to being settled through mediation.

Mediation in Poland is permitted in all civil cases where a settlement is admissible. That means that the subject matter of the dispute at stake would go to mediation, but only if the dispute would be subject to a state court's discretion.

According to the latest data presented by the EU Commission (EU Justice scoreboard 2020) Poland is one of the 4 most litigious countries in the EU. However, judges are encouraged to be applying more sustainable methods of dispute resolution such as mediation, especially at the preparatory stage of civil disputes. The figure below presents the dynamics of court-connected mediation cases and settled settled via mediation in 2017-2019.

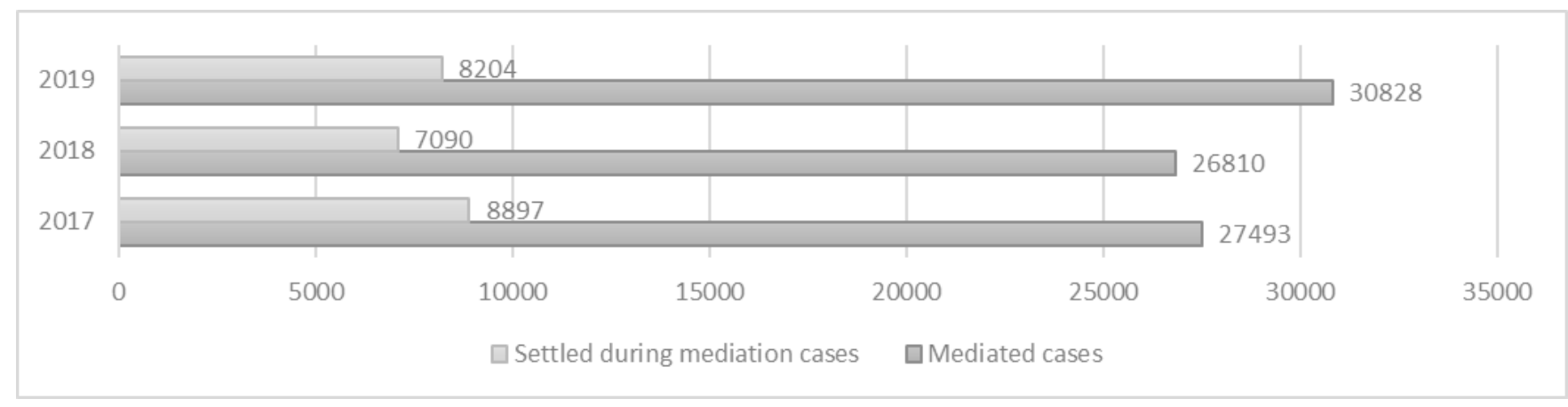

Figure 7: Number of mediations in Poland 2017-2019, and their success rate

Source: Ministry of Justice of Republic of Poland 2020

It is the law in Poland that mediation can be conducted either under a contract or by the appointment from a court (art. 183 Polish CCP). The mediation process takes place either prior to trial and/or, alternatively, if the parties agree during trial. 


\section{ENTREPRENEURSHIP AND SUSTAINABILITY ISSUES}

ISSN 2345-0282 (online) http://jssidoi.org/jesi/

2021 Volume 8 Number 3 (March)

http://doi.org/10.9770/jesi.2021.8.3(40)

Court appointed mediation is possible even if the parties have not previously been bound by a mediation provision in a contract or a specific mediation-contract. Such mediation can go forward if certain conditions are satisfied. First, the parties should agree to mediate and, second, it may take place only during the preliminary stage of litigation (until the first hearing). The notion of mandatory court-bound mediation does not exist in the polish legal system.

Parties to a dispute are encouraged to engage in mediation by judges. At the preparatory hearing, together with the parties, the chair judge shall determine the subject matter of the dispute and encourage the parties to reconcile, especially through mediation. Judges can act as conciliators on their own or advise to find a neutral mediator to deal with the case. There is, however, an assumption that the judge will assume an active role in negotiations between the parties. Although moderating the discussion between the parties is not anything new, the judge's "settlement" authority is quite broad. Therefore, a court settlement, a settlement reached/concluded in front of a mediator, as well as negotiations in front of a judge are all forms of amicable settlement made available to the parties in due process of the preparatory hearing (Flaga-Gieruszynska \& Zielinski 2019).

Notwithstanding all of the potential benefits of the preparatory hearing, there are several controversies that relate to the judges' direct participation in the negotiations between the parties. Scholars and practitioners argue that such an arrangement by a judge may be dangerous for three main reasons. First, during the preliminary hearing, a party does not have to be represented by counsel. Second, the principles of equality and neutrality may be compromised. Finally, early intervention into the process can result in major setbacks and ultimately can infringe upon the parties' substantial procedural rights (Marszałkowska-Krzes 2021). Poland's mediation laws have been criticized for not being clear enough in regard to the actual actions that will have to be undertaken by the judges during the preparatory stage. In spite of the fact that there are not any real incentives or repercussions for the judges, the forecast is that the judge's engagement will be limited (Mucha 2020).

Additionally, as evidenced by empirical research, judges may also be obstacles to effective mediation proceedings in Poland. One of the most comprehensive studies conducted in Poland has revealed major challenges to institutionalized mediation (Rudolf et al. 2014). Judges being convinced of their own conciliatory skills, their lack of specific mediation knowledge, and also low quality of mediation settlements are all elements having an overall impact on the way mediation is perceived and utilized in Poland.

A universal rule, in a scenario where parties do proceed to mediation through the appointment of the court (courtconnected mediation), they bear the costs of the proceeding (art. $183^{8}$ Polish CCP). In short, the mediator's salary can be determined through three different avenues depending on the type of mediation - it can be determined upon the basis of the Decree of the Ministry of Justice if it is a court-appointed mediation; on the basis of a mediation regulation in accordance with the payment tariff of the mediation center that the mediator acts on behalf of, or an individual agreement with the mediator if it is a contractual mediation.

In general, Polish civil procedure does not specifically distinguish requirements that ought to be met by mediators acting in court-connected mediation as opposed to contractual mediations. According to art. $183^{2} \S 2$ of the Polish Civil Code, in order to become a mediator, one has to be a natural person with full legal capacity, who is also exercising their innate rights. Thus, the law does not specify any formal requirements that have to be met by a mediator. However, there are exceptions. In divorce and separation cases (art. $436 \S 4$, Polish CCP), if the parties have not decided on the mediator, the court will refer them to a permanent mediator who has theoretical knowledge on matters which could be relevant to such disputes. Under the law there are two kinds of mediators in Poland: permanent and ad hoc.

Article $183^{2} \S 3$ specifies that nongovernmental organizations, public institutions (such as Universities) maintain lists of permanent mediators and create mediation centers. The lists of permanent mediators are forwarded to the 


\section{ENTREPRENEURSHIP AND SUSTAINABILITY ISSUES}

ISSN 2345-0282 (online) http://jssidoi.org/jesi/

2021 Volume 8 Number 3 (March)

http://doi.org/10.9770/jesi.2021.8.3(40)

president of the circuit court. Art $183^{2} \S 3{ }^{1}$ specifies that henceforth when the Act mentions a "mediator," it is a permanent mediator, unless the Code explicitly states otherwise. In consequence, the ad hoc mediator can be distinguished from the permanent mediator in the Polish system under the Polish CCP. A practical consequence of said differentiation is that institutions that ultimately maintain lists of permanent mediators may include additional criteria for a mediator to be enlisted. Such criteria may include specific training, knowledge, educational background, etc. Presidents of circuit courts maintain lists of permanent mediators. The requirements set forth by the Decree establishing the lists of permanent mediators are not extensive.

As of now the Ministry of Justice is introducing a novel mediator's registry called the National Mediator's Registry (Krajowy Rejestr Mediatorów), which would come into force during 2023. The NMR is designed to be a public registry of mediators conducting court and out-of-court mediations. Sparking much debate, The National Mediator's registry is an attempt to unify the profession and provide clear-cut requirements on skills and training. What is most important is that an existing registry, namely the Integrated Qualification System (Zintegrowany System Kwalifikacji), already enlists qualifications that have to be met by a mediator in civil and commercial cases. Therefore, it seems that in the coming years the profession will undergo further scrutiny relating to training, skills and expertise.

A permanent mediator can refuse to conduct mediation for valid reasons only. A mediator is under an obligation to inform the parties immediately of said refusal, and if the parties were appointed in a due process of trial, inform the court as well (art. $183^{2} \S 4$, Polish CCP).

What is important is that the Polish CCP introduces limitations on the appointment of judges as mediators. The Act specifies that although active judges cannot be mediators, the act does make an exception for judge emeriti. Under article 68 on the Common Court System, the general rule is that a judge retires at the age of 65 .

In Poland, mediation is advertised as a concept and an out-of-court dispute settlement procedure. For that reason, there are limited unified national measures undertaken to promote court-connected mediations. However, it must be appreciated that state courts do promote mediation through various information and social campaigns.

\section{Discussion, Conclusions and Recommendations}

Court-connected mediation in Lithuania was first introduced by adopting appropriate legal regulation and only later was applied in practice. Lithuanian researchers studied the legal regulation of mediation, its development, the peculiarities of its implementation and the possibility of applying mediation in different disputes. However, there is very little research done on the attitudes and experiences of judges and judges-mediators regarding courtconnected mediation.

The results of the completed quantitative and qualitative research revealed that both judges who deal with civil cases and judges-mediators of the Republic of Lithuania are generally positive about the system of courtconnected mediation. Both of the mentioned groups believe considerable attention is paid to court-connected mediation. The dispute parties are offered to resolve the dispute peacefully and to make use of the courtconnected mediation possibilities. Although the number of civil cases referred to court-connected mediation has been increasing over the past few years, this growth has recently stalled. While the results of the quantitative research revealed that judges see the lack of public awareness as one of the greatest obstacles to the development of the court-connected mediation, members of the focus groups expressed a bit different opinion. They mentioned the heavy workload, the incomplete accounting system for judges-mediators' workload and a decrease in the total number of civil cases as the main reasons hindering the development of the court-connected mediation in Lithuania. 


\section{ENTREPRENEURSHIP AND SUSTAINABILITY ISSUES}

ISSN 2345-0282 (online) http://jssidoi.org/jesi/

2021 Volume 8 Number 3 (March)

http://doi.org/10.9770/jesi.2021.8.3(40)

A study conducted by J. Sondaite and S. Molè (2019) titled "Attitudes of court mediators towards judicial mediation practice" revealed that after being offered court-connected mediation, the dispute parties tend to choose a judge as their mediator. Researchers refer to this as a kind of stereotype, linking these attitudes to the general assumption that the judge is a professional who is more knowledgeable in terms of the legal aspects of disputes. A study by S. B. Goldberg, M. L. Shaw, and J. M. Brett (2009) indicates the importance of the legal experience of judges-mediators when it comes to acquiring the dispute parties's trust. The authority and the legal knowledge of the judge-mediator encourages the dispute parties to get involved in mediation more actively in order to achieve a peaceful settlement. The conducted research confirms this idea. According to the judges and the judges-mediators, in most cases, dispute parties who are involved in the court mediation process want the mediator to be a judge. Not only is this due to their good knowledge of legal issues, but it is also because of their authority and the society's high confidence in them. The research also revealed the judges' positive attitude towards mediation, even if it does not end with a settlement. In their opinion, when the case returns to court from mediation, the emotional motives are already discussed, and so it is only the legal arrangements that remain to be made. This was also observed in a study conducted by J. Sondaite and S. Mole $(2019,203)$, where the court mediators mentioned that "even if a peace treaty is not signed after mediation, the dialogue still has its effects, the parties gain more clarity and the conflict becomes less intense in any case".

To summarize the results of the study, the need to explain the reasons for the dissatisfaction of judges with the court-connected mediation system in more detail is identified. There are several directions for the improvement of the institute of the court-connected mediation. First of all, both judges and judges-mediators see excessive workload of judges as the main obstacle for the development of the court-connected mediation. Given that there are judges who believe that court-connected mediation should not be conducted by judge-mediators at all, there is a need to discuss the possibility of more extensive involving of non-judges mediators in the process of courtconnected mediation. Secondly, according to judges and judges-mediators, court-connected mediation still lacks wider public awareness. Due to the fact that a large part of the public takes part in court disputes relatively infrequently and that the option of court-connected mediation is relevant only to those who are currently involved in litigation, one-time information distribution is not sufficient - consistent long-term publicity is needed. It should also be noted that some respondents mentioned the low competence and professionalism of mediators. It is necessary to ensure continuous professional development of judges-mediators, increase their motivation to stay active in mediation.

Taking a glace at the Polish model of court-connected mediation which does not involve judges as mediators at all, it is obvious that this approach may be seen as an alternative to the Lithuanian model. However, it should be noted that the success rate of court-connected mediation in Lithuania (47 per cent in 2019) is higher than in Poland (27 per cent in 2019). Such a difference may be caused by issues concerning mediators' qualification. In Poland the problem of mediator's qualification is related primarily to a fragmentary qualification and training system with little or no control as well as no unified measures applied. Fostering more sustainable measures designed to improvee the system of resolving civil disputes requires not only legal background, incentive measures but also a pool of professional mediators, who are ready to serve both in contract-based mediation and court-connected mediation. The existsing certification system of out-of-court mediatiors' in Lithuania and more than 500 mediators on the Lithuanian list of mediators is a strong argument for a comprehensive reform of the institutional model of the court-connected mediation in Lithuania. 


\section{ENTREPRENEURSHIP AND SUSTAINABILITY ISSUES}

ISSN 2345-0282 (online) http://jssidoi.org/jesi/

2021 Volume 8 Number 3 (March)

http://doi.org/10.9770/jesi.2021.8.3(40)

\section{References}

Ali, S. F. (2018). Court mediation reform: Efficiency, confidence and perceptions of Justice. Edward Elgar Publishing, 351 p.

Ali, S. F. (2018). Practitioners' Perception of Court-Connected Mediated in Five Regions: An Empirical Study. Vanderbilt Journal of Transnational Law, 51, no. 4 (October 2018): 997-1026. cdn.vanderbilt.edu

Annual Report of Lithuanian Courts. (2018). Constitutional Court of the Republic of Lithuania. available at https://www.lrkt.lt/data/public/uploads/2020/06/annual-report-2019-web_.pdf

Annual Report of Lithuanian Courts. (2019). Constitutional Court of the Republic of Lithuania. available at https://www.teismai.lt/data/public/uploads/2020/03/teismai2020.pdf

Art. 13, Rules on Court mediation, approved by the Council of Judges (19675 TAR 2018), available at https://www.etar.lt/portal/lt/legalAct/70208500f79411e880d0fe0db08fac89

Art. 6, part 2. Law on Mediation of the Republic of Lithuania (Valstybės žinios, 2008-07-31, Nr. 87-3462,. available at https://eseimas.lrs.lt/portal/legalAct/lt/TAD/TAIS.325294/asr

Code of Civil procedure of the Republic of Lithuania (36-1340, Valstybès žinios, 2002), available at https://www.etar.lt/portal/lt/legalAct/TAR.2E7C18F61454/asr

EU Justice Scoreboard 2020, available at: https://ec.europa.eu/info/policies/justice-and-fundamental-rights/upholding-rule-law/eu-justicescoreboard_en

Flaga-Gieruszyńska, K., Zieliński, A. (2019). Kodeks postępowania cywilnego (Code of Civil Procedure). Komentarz. Wyd. 10.

Gaižauskaitė, I. \& Mikènė, S. (2014). Socialinių tyrimų metodai: apklausa (Social research methods: survey). Vilnius: Mykolo Romerio universitetas, 215p.

Goldberg, S. B., Shaw, M. L., Brett, J. M. (2009). What Difference Does a Robe Make? Comparing Mediators with and without Prior Judicial Experience. Negotiation Journal, 25, 277-305. https://doi.org/10.1111/j.1571-9979.2009.00227.x

Kaminskiene, N., Tvaronaviciene, A. \& Zaleniene, I. (2014). Bringing sustainability into dispute resolution processes. Journal of Security and Sustainability Issues, 4(1), 69-77. https://doi.org/10.9770/jssi.2014.4.1(6)

Kaminskienè, N. (2010). Teisminè mediacija Lietuvoje. Quo vadis? Socialinis darbas, 9(1), 54-63.

Lande, J. (2004). Commentary: Focusing on program design issues in future research on court-connected mediation. Conflict Resolution, Quarterly 22(1), 89-100. https://doi.org/10.1002/crq.93

McAdoo, B., Welsh, N. \& Wissler, R. (2003). Institutionalization: What do empirical studies tell us about court mediation? Dispute Resolution Magazine, 9(2), 8-10. https://scholarship.law.tamu.edu/facscholar/990

Ministry of Justice of Poland, information on National Mediator's registry (2020), available at https://www.gov.pl/web/sprawiedliwosc/nowy-projekt-dla-mediacji--powstanie-krajowy-rejestr-mediatorow.

Molè, S. \& Sondaitė, J. (2019). Teismo mediatorių požiūris ị teisminès mediacijos praktiką. Socialinis darbas, 17 (2), $191-208$; https://doi.org/10.13165/SD-19-17-2-05

Morgan, D. L. (2010). Reconsidering the Role of Interaction in Analyzing and Reporting Focus Groups. Qualitative Health Research. 20 (5), 718 -722. https://doi.org/10.1177/1049732310364627

Mucha, J. [in:], Flaga-Gieruszyńska, K, Flejszar R, Malczyk M. (2020), Nowelizacja Kodeksu postępowania cywilnego (Amendment of the Code of Civil Procedure) z 4.7.2019 r. w praktyce.

Polish Civil Code, Journal of Laws 1964, No 16, item 93), available at http://isap.sejm.gov.pl/isap.nsf/download.xsp/WDU19640160093/U/D19640093Lj.pdf 


\section{ENTREPRENEURSHIP AND SUSTAINABILITY ISSUES}

ISSN 2345-0282 (online) http://jssidoi.org/jesi/

2021 Volume 8 Number 3 (March)

http://doi.org/10.9770/jesi.2021.8.3(40)

Rudolf, A. at al. (2014) Diagnoza stanu stosowania mediacji oraz przyczyny zbyt niskiej w stosunku do oczekiwanej popularności mediacji, Raport końcowy. Projekt: „Propagowanie alternatywnych metod rozwiązywania sporów” (Program operacyjny „Budowanie potencjału instytucjonalnego i współpraca w obszarze wymiary sprawiedliwości/Poprawa skuteczności wymiaru sprawiedliwości” realizowany w ramach Norweskiego Mechanizmu Finansowego 2009 - 2014). (Diagnosis of the application of mediation and the reason for its low popularity in relation to the expected popularity of mediation, Final report. Project: "Promoting alternative dispute resolution" (Operational program "Building institutional capacity and cooperation in the area of justice / Improving the efficiency of the justice system" implemented under the Norwegian Financial Mechanism 2009-2014).

Postępowanie Mediacyjne w świetle danych statystycznych, Sądy Rejonowe i Okręgowe w latach 2006 - 2019 (Mediation proceedings in the light of statistical data, District and District Courts in the years 2006 - 2019), available at: https://isws.ms.gov.pl/pl/bazastatystyczna/publikacje/download,2779,6.html

Rules on Court mediation, approved by the Council of Judges (19675 TAR 2018), available at https://www.etar.lt/portal/lt/legalAct/70208500f79411e880d0fe0db08fac89.

Saudargaitè, I. (2015). Judicial mediation in civil disputes in Lithuania. Dissertation. Vilnius, Mykolo Romerio universitetas.

The Act of July 272001 on the Common Court System, (Journal of Laws, No 98, item 1070 (Poland)), available at: http://isap.sejm.gov.pl/isap.nsf/download.xsp/WDU20010981070/U/D20011070Lj.pdf

The Act of 28.07.2005 amending the Code of Civil Procedure and other Acts, (Journal of Laws of 1964, Nr 43, item 269, with further amendments (Poland)), available at http://isap.sejm.gov.pl/isap.nsf/download.xsp/WDU20051721438/O/D20051438.pdf.

The Decree of the Minister of Justice of Poland of 20 January 2016 on maintaining lists of permanent mediators, (Journal of Laws of 2016, item 122), available at http://isap.sejm.gov.pl/isap.nsf/download.xsp/WDU20160000921/O/D20160921.pdf

The Decree of the Minister of Justice of Poland of 20 June, 2016 on mediator's salary and recovarable costs in civil litigation, (Journal of Laws 2016, item 921), available at http://isap.sejm.gov.pl/isap.nsf/download.xsp/WDU20160000921/O/D20160921.pdf

The Decree No. 13P-15 of Judicial Council of January 26, 2007 on the continuation of court mediation pilot project (Lithuania).

The Integrated Qualification System, qualifications of a mediator qualified in civil and commercial disputes (2021), available at: https://rejestr.kwalifikacje.gov.pl/frontend/index.php?r=kwalifikacja\%2Fview\&id=12632.

The list of court mediators, available at https://e.teismas.lt/lt/public/teismin\%C4\%97-mediacija/ (2021-01-12).

Tvaronavičienè, A. \& Kaminskienè, N. (2019). Teisminès mediacijos taikymas administracineje justicijoje (Application of judicial mediation in administrative justice). Lithuanian Law. Essential changes, 29-33. https://repository.mruni.eu/handle/007/16248

Welsh. N. A. (2004). The Place of Court-Connected Mediation in a Democratic Justice System. Cardozo Journal of Conflict Resolution, 5, 117-144. https://scholarship.law.tamu.edu/facscholar/948

Wissler, R. L. (2002). Court-Connected Mediation in General Civil Cases: What We Know from Empirical Research. Ohio State Journal on Dispute Resolution, 17(3), 641-704. http://hdl.handle.net/1811/87141

Wissler, R. L. (2002). The effectiveness of court-connected dispute resolution in civil cases. Conflict Resolution. Quarterly, 22(1), 55-88. https://doi.org/10.1002/crq. 92

Zaksaitè, S. \& Garalevičius, Z. (2009). Teisminès ir neteisminès šeimos ginčų mediacijos galimybės (Judicial and out-of-court mediation options for family disputes). Teisés problemos, 4(66), 70-108. 
Agnė TVARONAVIČIENÉ is a Professor at the Law School of Mykolas Romeris University. Research interests: alternative dispute resolution, mediation, public procurement, social technologies.

ORCID ID: orcid.org/0000-0002-5489-5570

Natalija KAMINSKIENE is an Associate Professor at the Law School of Mykolas Romeris University. Research interests: civil procedure, alternative dispute resolution, mediation, legal negotiations.

ORCID ID: orcid.org/0000-0002-0198-8271

Irena ŽEMAITAITYTÉ is a Professor at the Faculty of Human and Social Studies of Mykolas Romeris University. Research interests: adult education, formal and informal education, mediation.

ORCID ID: orcid.org/0000-0002-7773-9263

Maria CUDOWSKA is a junior lecturer at the Faculty of Law, University of Bialystok. Research interests: civil law, commercial law, alternative dispute resolution.

ORCID ID: orcid.org/0000-0002-8907-4211

Make your research more visible, join the Twitter account of ENTREPRENEURSHIP AND SUSTAINABILITY ISSUES: @ Entrepr6972881

Copyright (C) 2021 by author(s) and VsI Entrepreneurship and Sustainability Center

This work is licensed under the Creative Commons Attribution International License (CC BY).

http://creativecommons.org/licenses/by/4.0/

c) (i) Open Access 